\title{
Pengaruh Indeks Dow Jones, Nikkei 225, Shanghai Stock Exchange, Dan Straits Times Index Singapore Terhadap Indeks Harga Saham Gabungan (IHSG) Di Bursa Efek Indonesia (BEI)
}

\author{
Didit Herlianto \\ Universitas Pembangunan Nasional "Veteran" Yogyakarta \\ Luthfi Hafizh \\ Universitas Pembangunan Nasional “Veteran” Yogyakarta \\ Email: diditgatra@yahoo.co.id
}

\begin{abstract}
Tujuan penelitian ini adalah untuk menganalisis dan mengetahui pengaruh Indeks Dow Jones, Nikkei 225, Bursa Shanghai dan Indeks Singapore Straits Times terhadap Indeks Harga Saham Gabungan (IHSG) di Bursa Efek Indonesia 2015-2019. Teknik pengumpulan data dalam penelitian ini menggunakan metode dokumentasi yaitu dengan mencatat atau mendokumentasikan harga penutupan bulanan Dow Jones Industrial Average (DJIA), Nikkei 225, Shanghai Stock Exchange Composite Index (SSEC), Straits Times Index (STI) dan Indeks Perdagangan Saham Gabungan (IHSG). Hasil penelitian menunjukkan bahwa Indeks Dow Jones, Nikkei 225, Shanghai Stock Exchange Composite Indeks dan Straits Times Index Singapore secara simultan berpengaruh signifikan terhadap Indeks Harga Saham Gabungan (IHSG) di Bursa Efek Indonesia (BEI) periode 2015-2019. Indeks Dow Jones berpengaruh signifikan ke arah positif terhadap Indeks Harga Saham Gabungan (IHSG) di Bursa Efek Indonesia (BEI) periode 2015-2019. Nikkei 225 memiliki pengaruh signifikan ke arah negatif terhadap Indeks Harga Saham Gabungan (IHSG) di Bursa Efek Indonesia (BEI) Periode 2015-2019. Indeks Harga Saham Gabungan Shanghai Stock Exchange tidak berpengaruh signifikan terhadap Indeks Harga Saham Gabungan (IHSG) di Bursa Efek Indonesia (BEI) periode 2015-2019. Indeks Straits Times Singapura tidak berpengaruh signifikan terhadap Indeks Harga Saham Gabungan (IHSG) di Bursa Efek Indonesia (BEI) periode 2015-2019.
\end{abstract}

Kata Kunci: Indeks Rata-Rata Industri Dow Jones, Indeks Nikkei 225, Indeks Bursa Shanghai, Indeks Singapore Straits Times dan Indeks Harga Saham Gabungan.

\section{Pendahuluan}

\section{Latar Belakang}

Aktivitas berinvestasi saat ini sudah menjadi hal umum di berbagai kalangan masyarakat, karena dengan berinvestasi berharap mendapatkan keuntungan dari investasi tersebut untuk menjamin masa tua mereka bahkan untuk menggapai kemapanan finansialnya. Banyak jenis-jenis investasi yang ada, seperti investasi aset riil maupun investasi aset financials. Investasi riil secara umum melibatkan aset nyata seperti emas, silver, permata, tanah, dan real estate sedangkan investasi financial melibatkan kontrak-kontrak tertulis (atau elektronik) seperti saham dan obligasi (Jones 2006). Investasi asset financial dapat dilakukan di pasar modal, dimana pasar modal adalah tempat di perdagangkannya instrumen-instrumen financial asset tersebut. Pasar modal sendiri memiliki peranan penting bagi perekonomian suatu negara karena pasar modal dinilai mampu menjalankan 2 fungsi yaitu yang pertama adalah sebagai sarana bagi pendanaan usaha atau sebagai sarana bagi perusahaan untuk mendapatkan dana dari masyarakat pemodal (investor), dan yang ke dua yaitu pasar modal 


\section{Didit Herlianto, Luthfi Hafizh}

menjadi sarana bagi masyarakat untuk berinvestasi pada instrument keuangan seperti saham, obligasi, reksadana, dan lain- lain (www.idx.co.id). Tidak hanya itu pasar modal sendiri juga merupakan representasi untuk menilai kondisi perusahaan-perusahaan di suatu negara, ini disebabkan industri-industri di setiap negara masuk di pasar modal (Mauliano 2012). Transaksi di pasar modal sendiri sangat di pengaruhi oleh peristiwa yang terjadi, baik di dalam lingkup domestik maupun secara global, yang nantinya reaksi ini akan berpengaruh ke indikator seperti pergerakan harga saham (Surbakti 2011). Sebagai tolak ukur (benchmark) aktivitas atau kinerja pasar ekuitas suatu negara, maka digunakan indeks saham yang di perdagangkan di bursa suatu negara. Salah satu indeks yang digunakan sebagai referensi untuk menunjukkan kondisi pasar modal di Indonesia adalah Indeks Harga Saham Gabungan (IHSG) dimana IHSG sendiri mencatat setiap pergerakan saham yang tercatat di Bursa Efek Indonesia (Eun 1989). Banyak faktor yang dapat mempengaruhi pergerakan indeks saham, antara lain perubahan tingkat suku bunga bank sentral, keadaan ekonomi global, tingkat harga ekonomi dunia, tingkat harga energi dunia, kestabilan politik suatu negara dan variabel lainya (Blanchard 2006).

Globalisasi keuangan dengan dimensi yang kompleks merupakan factor eksternal yang mempengaruhi stabilitas sistem perekonomian maupun keuangan. Tidak diragukan lagi proses ini telah mengubah landscape dunia, tidak saja sector ekonomi, tetapi juga sektor lainnya. Perubahan utama sebagai dampak globalisasi keuangan adalah terjadinya lintas batas aliran keuangan dan pembayaran, semakin besarnya international risk-sharing melalui instrumen keuangan yang lebih beragam, meningkatnya lintas batas kepemilikan aset, serta meningkatnya profil pasar keuangan internasional, baik dari sisi pelaku pasar yang terlibat maupun institusinya. Dengan demikian, proses globalisasi keuangan akan membawa implikasi semakin terintegrasinya pasar modal suatu negara dengan pasar modal global (Salim 2017). Selain memberikan dampak positif, globalisasi keuangan sebenarnya juga menimbulkan dampak negatif yang patut diantisipasi dampak kelanjutannya, karena melibatkan proses transfer risiko serta biaya besar bagi suatu negara. Dalam hal ini, proses globalisasi keuangan akan menyebabkan perekonomian diberbagai negara menjadi lebih rentan terhadap guncangan. Pasar modal yang ada di Indonesia merupakan pasar yang sedang berkembang (emerging market) yang dalam perkembangannya sangat rentan terhadap kondisi perekonomian global. Pada tahun 2008 dimana terjadi krisis subprime mortgage di AS hampir semua bursa global mencatat penurunan yang besar sekaligus menorehkan catatan terburuk di Indonesia. Indeks Harga Saham Gabungan pada bulan Desember 2008 tercatat turun 51,17 persen ke level 1.340,89. Penurunan Indeks Dow Jones Industrial Average (DJIA) mambawa dampak negatif Indeks Harga Saham Gabungan di Bursa Efek Indonesia, mencatat penurunan yang terburuk ke empat setelah indeks saham di Shenzen, Shanghai, dan Mumbai (Tamara 2013).

Pergerakan Indeks Harga Saham Gabungan (IHSG) di Bursa Efek Indonesia tidak dapat dilepaskan dengan pergerakan indeks saham global lainya. Negara maju memiliki perekonomian yang kuat begitu pula terjadi pada indeks saham yang ada didalamnya. Indeks saham suatu negara merupakan refleksi dari kondisi perekonomian yang sedang terjadi. Turunnya nilai indeks saham suatu Negara mengindikasikan bahwa kondisi perekonomian negara tersebut sedang memburuk. Begitu juga sebaliknya, dengan adanya kenaikan indeks saham suatu negara maka dapat diindikasikan kondisi perekonomian negara tersebut sedang membaik (Danardono 2016). Keterkaitan antar bursa yang direpresentasikan oleh hubungan antar indeks harga saham dapat terjadi karena investor menjadikan pergerakan indeks harga saham di bursa lain sebagai salah satu informasi dalam proses pengambilan keputusan investasi (Tamara 2013). Penelitian tentang Pengaruh Indeks Harga Saham Global Terhadap 


\section{Didit Herlianto, Luthfi Hafizh}

Indeks Harga Saham Gabungan (IHSG) Studi Pada Bursa Efek Indonesia (BEI) Periode Tahun 2011-2014, menyebutkan bahwa pasar modal Indonesia melalui Bursa Efek Indonesia (BEI) merupakan bagian tak terpisahkan dari kegiatan bursa saham global (Tarigan dkk 2015).

Pasar modal sendiri juga merupakan representasi untuk menilai kondisi perusahaan perusahaan di suatu negara, ini disebabkan industri - industri di setiap negara masuk di pasar modal (Mauliano 2012). Belakangan ini pasar modal juga di jadikan indikator perekonomian suatu negara. Naik turunya indeks suatu bursa dapat di baca sebagai cermin dinamika ekonomi negara tersebut. Pada tahun 2018 China yang sedang perang dagang dengan AS, memberikan dampak negatif pada perekonomian global. China sebagai salah satu negara tujuan exspor terbesar Indonesia tentunya memberikan dampak negatif dari sisi perekonomian Indonesia sendiri, ditambah perlambatan ekonomi global kemudian menyebabkan harga dan permintaan komoditas yang menjadi andalan ekspor Indonesia semakin tersungkur. Untuk menggambarkan kondisi pasar modal dan ekonomi China, digunakan Indeks Shanghai Stock Exchange Composite (SSEC). Indeks lain yang sering digunakan untuk pengambilan keputusan para investor adalah Nikkei 225 (N225) yang dimana merupakan indeks harga saham gabungan negara Jepang. Per Juli 2019 Jepang merupakan salah satu tujuan ekspor non-migas terbesar setelah AS dan China dengan porsi 8,99\% (BPS), yang berarti Indeks Nikkei 225 berpengaruh positif terhadap IHSG di Bursa Efek Indonesai (Immanuel dan Wirawan 2017).

Selain ke tiga Indeks di atas, Index Straits Times Singapore (STI) merupakan Indeks lain yang bisa di gunakan dalam pengambilan keputusan oleh para investor dimana Index Straits Times Singapore merupakan indeks utama Singapore. Singapore Sendiri merupakan salah satu negara yang masuk dalam ASEAN dengan tujuan expor tertinggi diantara negara ASEAN lainya. Berdasarkan latar belakang dan juga fenomena yang terjadi diatas maka dalam penelitian ini dapat dirumuskan beberapa permasalahan sebagai berikut: 1) Apakah Indeks Dow Jones, Nikkei 225, Shanghai Stock Exchange Composite Index dan Straits Times Index Singapore berpengaruh bersama-sama terhadap Indeks Harga Saham Gabungan (IHSG) di Bursa Efek Indonesia Tahun 2015-2019; 2) Apakah Indeks Dow Jones berpengaruh terhadap Indeks Harga Saham Gabungan di Bursa Efek Indonesia Tahun 20152019; 3) Apakah Indeks Nikkei 225 berpengaruh terhadap Indeks Harga Saham Gabungan di Bursa Efek Indonesia Tahun 2015-2019; 4) Apakah Shanghai Stock Exchange Composite Index berpengaruh terhadap Indeks Harga Saham Gabungan di Bursa Efek Indonesia Tahun 2015-2019; 5) Apakah Indeks Straits Times Singapore berpengaruh terhadap Indeks Harga Saham Gabungan di Bursa Efek Indonesia Tahun 2015 - 2019.

Dari perumusan masalah tersebut diatas maka tujuan penelitian ini adalah: 1) Untuk menganalisis dan mengetahui Pengaruh Indeks Dow Jones, Nikkei 225, Shang Hai Stock Exchange dan Indeks Straits Times Singapore terhadap Indeks Harga Saham Gabungan (IHSG) di Bursa Efek Indonesia Tahun 2015-2019; 2) Untuk menganalisis dan mengetahui pengaruh Indeks Dow Jones terhadap Indeks Harga Saham Gabungan di Bursa Efek IndonesiaTahun 2015-2019; 3) Untuk menganalisis dan mengetahui pengaruh Indeks Nikkei 225 terhadap Indeks Harga Saham Gabungan di Bursa Efek Indonesia Tahun 2015-2019; 4) Untuk menganalisis dan mengetahui Shanghai Stock Exchange Composite Index terhadap Indeks Harga Saham Gabungan di Bursa Efek IndonesiaTahun 2015-2019; 5) Untuk menganalisis dan mengetahui pengaruh Indeks Straits Times Singapore terhadap Indeks Harga Saham Gabungan di Bursa Efek Indonesia Tahun 2015-2019. 


\section{Landasan Teori dan Pengembangan Hipotesis}

\section{Landasan Teori}

\section{Investasi}

Investasi dapat diartikan sebagai komitmen untuk menanamkan sejumlah dana pada saat ini dengan tujuan memperoleh keuntungan di masa mendatang (Tandelilin 2010). Investasi adalah menanamkan modal (uang) dalam suatu instrumen investasi (portofolio investasi) dengan harapan di masa depan nilai kekayaan (assets) tersebut semakin meningkat dan besar. Investasi dilihat dari tujuan, terdiri dari investasi jangka panjang dan jangka pendek. Investasi jangka pendek kurang dari satu tahun, sedangkan jangka panjang lebih dari satu tahun ke atas hingga dua tahun dan seterusnya. Instrumen Investasi dikelompokkan menjadi dua: (2) investasi di sektor keuangan (financial assets); (1) investasi di sektor riil (real assets) atau properti (Didin 2017).

\section{Pasar Modal}

Pasar modal merupakan tempat bertemu antara pembeli dan penjual dengan risiko untung dan rugi. Pasar modal merupakan sarana perusahaan untuk meningkatkan kebutuhan dana jangka panjang dengan menjual saham atau mengeluarkan obligasi. Saham merupakan bukti kepemilikan sebagian perusahaan. Obligasi (bond) merupakan suatu kontrak yang mengharuskan peminjam untuk membayar kembali pokok pinjaman ditambah dengan bunga dalam kurun waktu tertentu yang sudah disepakati. Untuk menarik pembeli dan penjual berpartisipasi, pasar modal harus bersifat likuid dan efisien. Suatu pasar modal dikatakan likuid jika penjual dapat menjual dan pembeli dapat membeli surat-surat berharga dengan cepat. Pasar modal dikatakan efisien jika harga dari surat-surat berharga mencerminkan nilai dari perusahaan secara akurat. Dengan demikian pasar modal dapat digunakan sebagai sarana tidak langsung pengukur kualitas manajemen (Jogiyanto 2017).

Instrumen pasar modal adalah semua surat berharga (efek) yang secara umum diperjualbelikan melalui pasar modal. Menurut Undang-undang Nomor 8 Tahun 1995 tentang pasar modal, efek adalah setiap surat pengakuan utang, surat berharga komersial, saham, obligasi, sekuritas kredit, tanda bukti utang, setiap right, waran, opsi, atau derivatif dari efek, atau setiap instrumen yang ditetapkan sebagai efek. Umumnya sekuritas yang diperdagangkan di pasar modal meliputi saham, obligasi, reksadana dan instrumen derivatif.

\section{Kointegrasi Pasar Modal}

Fenomena globalisasi pada umumnya ditandai dengan meningkatnya perdagangan antar negara, yang meningkatkan indikasi investasi asing, kemajuan teknologi dan faktor lainnya. Dengan demikian, pasar modal internasinal menjadi terintegrasi. Deregulasi pasar dan liberalisasi, pengembangan teknologi dan komunikasi, inovasi dalam produk keuangan dan layanan merupakan beberapa dampak kointegrasi antar negara di dunia (Banner dan Kroner 1995). Contagion diidentifikasi sebagai proses umum dari transmisi shocks (guncangan) antar negara. Definisi ini berlaku dalam dua kondisi yaitu pada periode stabil maupun krisis dan tidak hanya berhubungan dengan dampak negatif suatu efek tetapi juga dengan dampak positif dari pergerakan negara lain. Terdapat dua penyebab terjadinya contagion, yaitu fundamental causes dan investor behavior (Dornbusch et al 2000): 


\section{Didit Herlianto, Luthfi Hafizh}

1) Fundamental Causes; Contagion yang bersumber dari fundamental dapat terjadi disebabkan 3 hal, yaitu common shocks, trade links \& competitive devaluations, financial links. Common Shock merupakan identifikasi berbagai shock global yang dapat memicu penyesuaian pasar dalam konteks internasional. Penyebab global yang umum, seperti pergeseran ekonomi besar di negara-negara industri dan perubahan harga komoditas, dapat memicu krisis pasar negara berkembang (Hjalmarsson dan Osterholm, 2007). Trade links \& competitive devaluations merupakan local shock yang dapat mempengaruhi fundamental ekonomi negara-negara lain melalui jalur perdagangan dan devaluasi mata uang. Setiap mitra dagang utama akan mengalami krisis keuangan yang menyebabkan depresiasi mata uang, penurunan harga aset dan arus modal keluar yang besar dan spekulatif. Financial Link merupakan Integrasi ekonomi suatu negara secara individu ke dalam pasar dunia biasanya melibatkan hubungan perdagangan dan keuangan.

2) Investor Behavior; Contagion juga dapat didasari oleh perilaku dari para investor. Semakin erat tingkat kointegrasi antar perekonomian negara maka akan semakin besar efek dari contagion dari satu negara terhadap negara lain. Sedangkan negara yang terkointegrasi tidak akan merespon shock apabila terjadi contagion diantara negaranegara yang terintegrasi tersebut.

\section{Indeks Harga Saham}

Informasi mengenai kinerja pasar saham seringkali diringkas dalam suatu indeks yang disebut indeks pasar saham (stock market index). Indeks pasar saham merupakan indikator yang mencerminkan kinerja saham-saham di pasar modal. Karena merupakan indikator yang menggambarkan harga - harga saham, maka indeks pasar saham juga sering disebut indeks harga saham (stock price index). Pergerakan indeks menjadi indikator penting bagi para investor untuk menentukan apakah mereka akan menjual, menahan atau membeli suatu atau beberapa saham.

Indeks Harga Saham yang terkait dengan penelitian ini meliputi: 1) Indeks Harga Saham Gabungan BEI; 2) Indeks Dow Jones; 3) Indeks Nikkei 225; 4) Indeks Shanghai Stock Exchange; 5) Straits Times Index Singapore.

\section{Indeks Harga Saham Gabungan BEI}

Indeks Harga Saham Gabungan menggambarkan suatu rangkaian informasi historis mengenai pergerakan harga saham gabungan seluruh saham, sampai pada tanggal tertentu. Indeks Harga Saham Gabungan (IHSG) pertama kali diperkenalkan pada tanggal 1 April 1983 sebagai indikator pergerakan harga saham yang tercatat di bursa. Harga dasar perhitungan indeks adalah tanggal 10 Agustus 1982 dengan nilai 100. Sedangkan jumlah emiten yang tercatat pada waktu itu adalah sebanyak 13 emiten (Buku Panduan Indeks 2010). Perhitungan Indeks Harga Saham Gabungan mencakup seluruh saham yang terdaftar di Bursa Efek Indonesia (BEI). IHSG yang ada di BEI dihitung menggunakan metodologi rata-rata tertimbang berdasarkan jumlah saham tercatat (nilai pasar) atau Market Value Weighted Average Index. Formula dasar perhitungan indeks adalah: 


$$
\text { IHSG }=\frac{\text { Nilai Pasar }(\mathrm{P} 1 . \mathrm{Q} 1+\mathrm{P} 2 . \mathrm{Q} 2+\ldots+\mathrm{Pi} . \mathrm{Q} \mathrm{i}+\mathrm{Pn} . \mathrm{Qn})}{\text { (Nilai Dasar) }} \times 100
$$

Keterangan:

$\mathrm{P}=$ Closing Price (harga yang terjadi) untuk emiten ke-i;

$\mathrm{Q}=$ Jumlah saham yang digunakan untuk perhitungan indeks (jumlah saham yang tercatat) untuk emiten ke-i;

$\mathrm{n}=$ Jumlah emiten yang tercatat di BEI (jumlah emiten yang digunakan untuk perhitungan indeks).

Nilai dasar adalah kumulatif jumlah saham pada hari dasar dikali dengan harga pada hari dasar. Hari dasar untuk IHSG adalah 10 Agustus 1982 yang ditetapkan sebesar 100.

\section{Indeks Dow Jones Industrial Average}

Dow Jones Industrial Average (DJIA) adalah salah satu indeks pasar saham yang didirikan oleh editor The Wall Street Journal dan pendiri Dow Jones \& Company Charles Dow. Dow membuat indeks ini sebagai suatu cara untuk mengukur performa komponen industri di pasar saham Amerika. Saat ini DJIA merupakan indeks pasar AS tertua yang masih berjalan (www.en.wikipedia.org). Cara penghitungan indeks Dow Jones sebagai berikut (www.nyse.com):

$$
\text { DJIA }=\frac{\sum p}{d}
$$

Keterangan:

$\mathrm{P}=$ Jumlah seluruh harga saham;

$\mathrm{d}$ = Divisor. Divisor adalah angka yang ditentukan oleh Dow Jones sebagai pembagi. Angka pembagi ini selalu diperbaharui dan disesuaikan dengan perkembangan pasar yang terjadi seperti stock split, pembayaran dividen, pengumuman bonus, dan berita ekonomi lain. Dow Divisor per April 2019 adalah 0,14744568353097 dan setiap perubahan \$ 1 dalam harga pada saham tertentu dalam rata-rata setara dengan pergerakan poin 6,782 (atau $1 \div$ 0,14744568353097). Dow Divisor sangat penting dalam menghitung tingkat DJIA. Hal ini bertujuan untuk menjaga agar nilai indeks tetap konsisten.

\section{Indeks Nikkei 225}

Nikkei 225 adalah sebuah indeks pasar saham di Bursa Efek Tokyo. Indeks ini telah dihitung oleh harian Nihon Keizai Shimbun (Nikkei) sejak 7 September 1950. Metode perhitungannya menggunakan perhitungan harga rata-rata (unit dalam yen), dan komponen saham perusahaan yang tercantum dalam indeks akan ditinjau setahun sekali. Saham perusahaan yang tercatat dalam Indeks Nikkei 225 merupakan saham yang paling aktif diperdagangkan dalam bursa efek Tokyo. Saat ini, Nikkei adalah indeks yang paling banyak digunakan sebagai panduan bagi investor ketika akan berinvestasi (www.en.wikipedia.org). Cara penghitungan Indeks Nikkei 225 sendiri sebagai berikut (www.nni.nikkei.co.jp): 
Didit Herlianto, Luthfi Hafizh

Keterangan:

Nikkei $225: \frac{\sum P}{\text { Divisor }}$

$\mathrm{P}=$ Jumlah seluruh harga saham;

$\mathrm{d}=$ Divisor. Dimana berbagai macam event yang terjadi di pasar saham Tokyo seperti stock splits, perpindahan dan penambahan dari saham yang beredar akan memberikan dampak atas perhitungan indeks dan bilangan pembaginya (divisor).

\section{Indeks SSE composite Index}

Indeks SSE adalah indeks statistik otoritatif yang banyak diikuti dan digunakan di dalam dan luar negeri untuk mengukur kinerja pasar sekuritas Tiongkok. Seri Indeks SSE terdiri dari 75 indeks, termasuk 69 indeks ekuitas, 5 indeks obligasi, dan 1 indeks dana, yang mencakup beberapa seri seperti ukuran pasar, sektor, gaya, strategi dan seri tematik dan menjadi sistem indeks yang terus ditingkatkan. SSE Composite Index mengambil 19 Desember 1990 sebagai hari dasar dan total kapitalisasi pasar dari semua saham yang terdaftar pada hari yang sama dengan periode dasar, dengan basis 100 poin. Itu diterbitkan dari 15 Juli 1991 dan merupakan indeks yang paling banyak digunakan di pasar sekuritas Cina. Indeks SSE adalah pasar papan utama Tiongkok yang juga secara luas dianggap sebagai Pasar Blue-chip di Cina. Dimana indeks ini terdiri dari sejumlah raksasa industri dengan tingkat pertumbuhan yang tinggi, kinerja yang stabil dan profitabilitas yang solid. Dengan pengembangan lebih dari 20 tahun, pasar ekuitas blue-chip multi-tier SSE sekarang mencakup 3 tingkatan (http://english.sse.com.cn/). Cara penghitungan Shanghai Stock Ecxchange Composite Index sendiri sebagai berikut (https://www.investopedia.com/terms/s/sse-composite.asp):

$$
\text { Current Index: } \frac{\text { Market Cap of Composite Members }}{\text { Base Period }} x \text { Base Value }
$$

Indeks ini dibuat untuk mencerminkan kondisi pasar saham, oleh karena itu pergerakan setiap indeks sektor industri dinilai setara dan tidak ada pembobotan yang lebih untuk sektor - sektor industri tertentu (www.nni.nikkei.co.jp/e/cf/fr/market/nikkeiindex.cfm).

\section{Straits Times Idex Singapore}

Straits Times Index Singapore adalah sebuah indeks pasar saham berdasarkan kapitalisasi di bursa efek Singapura. Indeks ini digunakan untuk mendata dan memonitor perubahan harian dari 30 perusahaan terbesar di pasar saham Singapura dan sebagai indikator utama dari performa pasar di Singapura.Cara penghitungan Straits Times Index Singapore sendiri sebagai berikut (Straits Times Index Ground Rules):

Keterangan :

$$
\sum_{i=1}^{N} \frac{\left(p_{i} \times e_{i} \times s_{i} \times f_{i}\right)}{d}
$$

$\mathrm{N}=$ jumlah sekuritas yang tercatat;

$\mathrm{p}_{\mathrm{i}}=$ harga terbaru yang tercatat;

$\mathrm{e}_{\mathrm{i}}=$ nilai tukar;

$\mathrm{S}_{\mathrm{i}}=$ jumlah saham yang di terbitkan; 
INOBIS: Jurnal Inovasi Bisnis dan Manajemen Indonesia

Volume 03, Nomor 02, Maret 2020

Didit Herlianto, Luthfi Hafizh

$\mathrm{f}_{\mathrm{i}}=$ Investability Weighting Factor;

$\mathrm{d}=$ divisor.

\section{Pengembangan Hipotesis}

\section{Pengaruh Indeks Dow Jones terhadap IHSG}

Indeks Dow Jones (DJIA) merupakan salah satu dari 3 indeks utama di Amerika Serikat. Indeks yang lain adalah Nasdaq Composite dan Standard \& Poor's 500. Indeks ini merepresentasikan dari kegiatan perekonomian di Amerika Serikat. Indeks ini dapat menggambarkan mengenai bagaimana performa perekonomian Amerika. Menurut Sunariyah (2011), dengan naiknya Indeks Dow Jones ini berarti kinerja perekonomian Amerika Serikat ikut membaik. Pergerakan Indeks Dow Jones akan mempengaruhi pergerakan IHSG juga. Karena sebagai salah satu negara tujuan ekspor Indonesia, pertumbuhan ekonomi Amerika Serikat dapat mendorong pertumbuhan ekonomi Indonesia melalui kegiatan ekspor maupun aliran modal masuk baik investasi langsung maupun melalui pasar modal.

\section{Pengaruh Indeks Nikkei 225 terhadap IHSG}

Saham perusahaan yang tercatat dalam Indeks Nikkei 225 merupakan saham yang paling aktif diperdagangkan dalam bursa efek Tokyo, dan juga perusahaan yang tercatat di Indeks Nikkei 225 merupakan perusahaan besar yang telah beroperasi secara global, termasuk di Indonesia. Dengan naiknya Indeks Nikkei 225 ini berarti kinerja perekonomian Jepang ikut membaik. Karena sebagai salah satu negara tujuan ekspor Indonesia, pertumbuhan ekonomi Jepang dapat mendorong pertumbuhan ekonomi Indonesia melalui kegiatan ekspor maupun aliran modal masuk baik investasi langsung maupun melalui pasar modal (Sunariyah 2011). Sehingga pergerakan dari Indeks Nikkei 225 akan mempengaruhi IHSG.

\section{Pengaruh Shanghai Stock Exchange Composite Index terhadap IHSG}

Shanghai Stock Exchange (SSE) Composite Index terdiri dari semua saham yang tercatat (termasuk saham tipe A dan B) di Shanghai Stock Exchange. Indeks ini bertujuan untuk mencerminkan keseluruhan kinerja pasar saham Shanghai (www.bloomberg.com), sehingga naiknya indeks ini mempresentasikan kinerja perekonomian Cina ikut membaik. Cina sebagai salah satu tujuan ekspor terbesar Indonesia maka naik atau turunya perekonomian Cina akan berpengaruh terhadap Indonesia, semua hal tersebut dapat tercermin di kondisi bursa masing - masing negara. Sehingga pergerakan dari Shanghai Stock Exchange (SSE) Composite Index akan mempengaruhi IHSG. (Samsul 2006) mengemukakan bahwa pasar modal Indonesia sudah terintegrasi dengan pasar modal dunia hal ini menimbulkan konsekuensi bahwa pergerakan pasar modal Indonesia akan dipengaruhi oleh pergerakan pasar modal dunia baik secara langsung maupun tidak langsung.

\section{Pengaruh Straits Times Index (STI) terhadap IHSG}

Straits Times Index (STI) merupakan indeks saham di pasar modal Singapura. Singapura dan Indonesia merupakan anggota ASEAN yang memiliki perjanjian ekonomi yaitu AFTA (Asean Free Trade Area), dimana AFTA merupakan perjanjian ekonomi perdagangan bebas di kawasan Asia Tenggara. Dengan adanya pernjanjian perdagangan 
bebas hal ini menyebabkan ekonomi kedua negara memiliki hubungan yang kuat. Hubungan ekonomi tersebut dapat dilihat dari pasar modal pada masing-masing negara, dimana investor Indonesia secara bebas menginvestasikan dananya di Pasar Modal Singapura, dan sebaliknya, investor Singapura memiliki kebebasan untuk berinvestasi di Pasar Modal Indonesia. Sehingga pergerakan dari Straits Times Index (STI) akan mempengaruhi IHSG.

\section{Kerangka Pemikiran}

Kerangka pemikiran dalam penelitian ini berfokus pada varabel terikat (varibel dependen) yang dipengaruhi oleh variabel bebas (varibel independen). Dalam penelitian ini yang menjadi varibel independen adalah Dow Jones Industrial Average $\left(\mathrm{X}_{1}\right)$, Indeks Nikkei $225\left(\mathrm{X}_{2}\right)$, Shanghai Stock Exchange Composite Index $\left(\mathrm{X}_{3}\right)$ dan Straits Times Index $\left(\mathrm{X}_{4}\right)$, sedangkan variabel dependennya adalah Indeks Harga Saham Gabungan (Y). Kerangka dalam penelitian ini digambarkan sebagai berikut (Gambar 1):

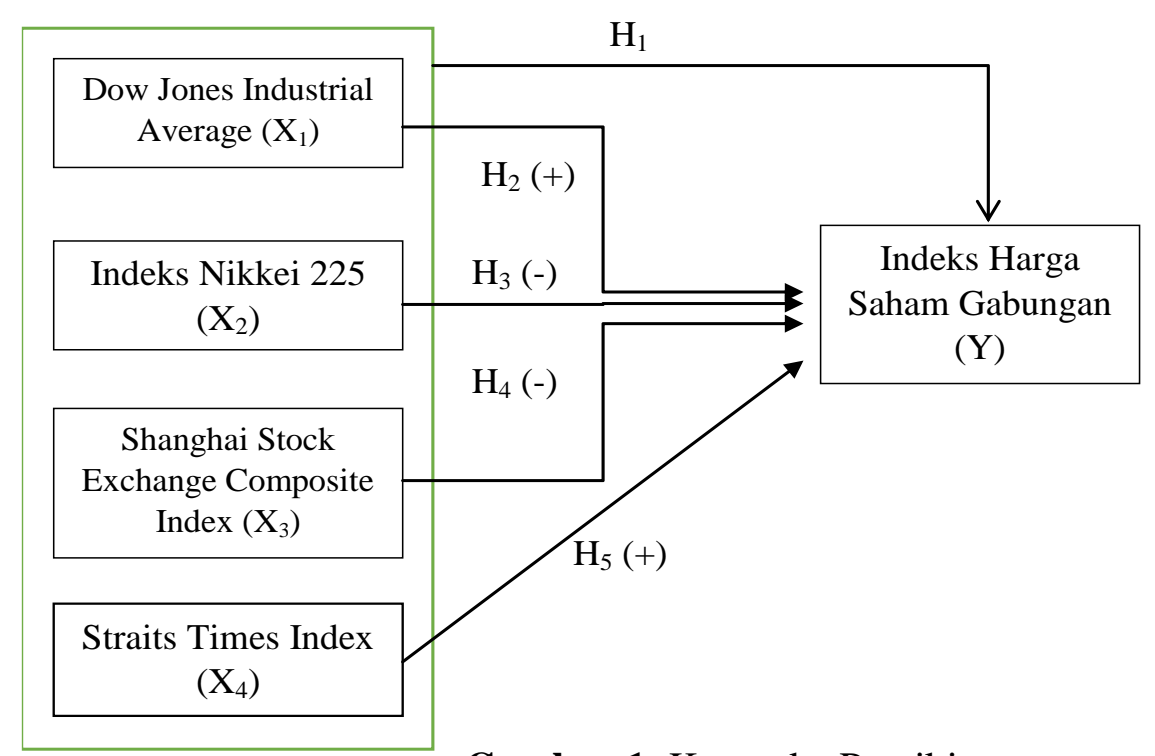

Gambar 1. Kerangka Pemikiran

\section{Hipotesis Penelitian}

Berdasarkan pada landasan teori dan hasil penelitian terdahulu, maka dalam penelitian ini dapat dikembangkan hipotesis sebagai berikut :

1) $\mathrm{H}_{1}$ : Indeks Dow Jones, Indeks Nikkei 225, Shanghai Stock Exchange Composite Indeks, dan Indeks Straits Times secara bersama-sama berpengaruh signifikan terhadap IHSG di Bursa Efek Indonesia periode 2015 - 2019.

2) $\mathrm{H}_{2}$ : Indeks Dow Jones berpengaruh signifikan dengan arah positif terhadap IHSG di Bursa Efek Indonesia periode 2015 - 2019.

3) $\mathrm{H}_{3}$ : Indeks Nikkei 225 berpengaruh signifikan dengan arah negatif terhadap IHSG di Bursa Efek Indonesia periode 2015 - 2019.

4) $\mathrm{H}_{4}$ : Shanghai Stock Exchange Composite Index berpengaruh signifikan dengan arah negatif terhadap IHSG di Bursa Efek Indonesia periode 2015 - 2019.

5) $\mathrm{H}_{5}$ : Indeks Straits Times berpengaruh signifikan dengan arah positif terhadap IHSG di Bursa Efek Indonesia periode 2015 - 2019. 
Didit Herlianto, Luthfi Hafizh

\section{Metode Penelitian}

\section{Rancangan Penelitian}

Penelitian ini merupakan penelitian penjelasan (expanatory research) dengan tujuan untuk memperoleh bukti empiris serta menguji hipotesis yang diajukan mengenai pengaruh variable DJIA, Nikkei 225, SSE Composite Index, dan Straits Times Index Singapura berpengaruh sebagai variable independent terhadap IHSG sebagai variable dependent. Data yang digunakan pada penelitian ini adalah data time series.

\section{Populasi dan Sampel}

Populasi dalam penelitian ini adalah Indeks Saham Gabungan Global yang berjumlah 106 indeks utama pada setiap negara, dengan sampel sebagai berikut New York Stock Echange dengan Indek Dow Jones (DJIA), Tokyo Stock Exchange dengan Indeks Nikkei 225 (N225), Shanghai Stock Exchange dengan SSE Composite Indeks (SSEC), dan Singapore Exchange dengan Straits Times Index, data yang digunakan adalah data periode Januari 2015 hingga Desember 2019.

\section{Jenis Data Penelitian}

Penelitian ini menggunakan data yang bersifat sekunder, menurut Istijanto (2009), data sekunder adalah data yang telah dikumpulkan oleh pihak lain (bukan oleh periset sendiri) untuk tujuan lain. Data sekunder adalah data yang didapat dan disimpan oleh orang lain yang biasanya merupakan data masa lalu (historical).

\section{Prosedur Pengambilan Data}

Tekhnik pengambilan data pada penelitian ini menggunakan metode dokumentasi, yaitu dengan mencatat atau mendokumentasikan harga penutupan bulanan Dow Jones Industrial Average (DJIA), Nikkei 225, Shanghai Stock Exchange Composite Index (SSEC), Straits Times Index (STI) dan Indek Haga Saham Gabungan (IHSG) yang terdapat pada website finance.yahoo.com. dan www.investing.com.

\section{Definisi Operasional Variabel}

Variabel-variabel dalam penelitian ini dikelompokkan menjadi variabel dependen dan variabel independen, sebagai berikut:

1) Variabel terikat (Y) atau "dependent variable" yaitu variabel yang dipengaruhi oleh variabel bebas. Variabel terikat dalam penelitian ini adalah Indeks Harga Saham Gabungan (IHSG). Dalam penelitian ini data yang digunakan adalah data IHSG bulanan selama empat tahun mulai Januari 20015 - Desember 2019.

2) Variabel bebas (X) atau "independent variable" merupakan veriabel yang dapat mempengaruhi variabel terikat "dependent variable". Variabel-variabel bebas dalam penelitian ini meliputi:

a. Indeks Dow Jones $\left(\mathrm{X}_{1}\right)$

Indeks Dow Jones (DJIA) merupakan indeks yang dapat digunakan untuk mengukur performa kinerja perusahaan yang bergerak di sektor industri di Amerika Serikat. Dikarenakan perbedaan waktu New York lebih lambat 11 jam dari Waktu Indonesia Barat (WIB) data DJIA yang digunakan dalam penelitian ini adalah data 
penutupan sehari sebelum tanggal akhir bulan selama periode Januari 2015 Desember 2019.

\section{b. Indeks Nikkei $225\left(\mathrm{X}_{2}\right)$}

Indeks Nikkei 225 (N225) merupakan gabungan dari 225 perusahaan yang terpilih, dengan persyaratan tertentu. Perusahaan yang terpilih merupakan perusahaan yang memiliki asset yang besar dan memiliki kredibilitas yang baik di market. Data yang digunakan dalam penelitian ini adalah data penutupan sehari sebelum penutupan bulanan selama periode Januari 2015 - Desember 2019.

\section{c. Indeks SSE Composite $\left(\mathrm{X}_{3}\right)$}

Shanghai Stock Exchange Composite Index terdiri dari semua saham yang tercatat di Shanghai Stock Exchange, Indeks ini bertujuan untuk mencerminkan keseluruhan kinerja pasar saham Shanghai. Data yang digunakan dalam penelitian ini adalah data penutupan bulanan selama periode Januari 2015 - Desember 2019.

\section{d. Indeks Straits Times $\left(\mathrm{X}_{4}\right)$}

Straits Times Index Singapore adalah sebuah indeks pasar saham berdasarkan kapitalisasi di bursa efek Singapura. Indeks ini digunakan untuk mendata dan memonitor perubahan harian dari 30 perusahaan terbesar di pasar saham Singapura dan sebagai indikator utama dari performa pasar di Singapura. Data yang digunakan dalam penelitian ini adalah data penutupan bulanan selama periode Januari 2015 Desember 2019.

\section{Metode Analisis Data}

Metode analisis data yang digunakan dalam penelitian ini adalah analisis data kuantitatif, untuk memperkirakan secara kuantitatif pengaruh dari beberapa variabel independen secara bersama-sama (simultan) maupun secara parsial (individu) terhadap variabel dependen. Hubungan fungsional antara variabel independen dengan variabel dependen dapat dilakukan dengan regresi berganda. Metode analisis yang digunakan adalah regresi Model Linier dengan model sebagai berikut :

$$
Y=a+b_{1} X_{1}+b_{2} X_{2}+b_{3} X_{3}+b_{4} X_{4}+e
$$

Keterangan:

$\mathrm{Y}=$ Indeks harga saham gabungan (IHSG);

$\mathrm{a}=$ konstanta;

$\mathrm{b}_{1}, \mathrm{~b}_{2}, \mathrm{~b}_{3}, \mathrm{~b}_{4}=$ koefisien regresi;

$\mathrm{X}_{1}=$ Indeks Dow Jones;

$\mathrm{X}_{2}=$ Indeks Nikkei 225;

$\mathrm{X}_{3}=\mathrm{SSE}$ Composite Index;

$\mathrm{X}_{4}=$ Straits Times Index . 
Untuk uji hipotesis dalam penelitian meliputi:

1) Uji Signifikansi Simultan (Uji F)

Uji statistik F pada dasarnya menunjukkan apakah semua varibel independen atau bebas yang dimasukkan dalam model mempunyai pengaruh secara bersama- sama terhadap variabel dependen/terikat (Ghozali 2011). Di dalam penelitian ini uji $\mathrm{F}$ digunakan untuk menguji pengaruh Indeks DJIA, N225, SSEC dan STI terhadap IHSG secara simultan terhadap IHSG. Menurut Ghozali (2011), uji F dilakukan dengan membandingkan signifikansi $\mathrm{F}$ hitung dengan $\mathrm{F}$ tabel dengan ketentuan:

- $\mathrm{H}_{0}$ diterima dan $\mathrm{H}_{\mathrm{a}}$ ditolak jika $\mathrm{F}$ hitung $<\mathrm{F}$ tabel untuk $\alpha=0,05$

- $\mathrm{H}_{0}$ ditolak dan $\mathrm{H}_{\mathrm{a}}$ diterima jika $\mathrm{F}$ hitung > $\mathrm{F}$ tabel untuk $\alpha=0,05$

2) Uji Signifikan Parsial (Uji t)

Uji statistik $\mathrm{t}$ pada dasarnya menunjukkan seberapa jauh pengaruh satu variabel penjelas/independen secara individual dalam menerangkan variabel dependen (Ghozali 2011). Dalam penelitian ini uji $t$ digunakan untuk menguji hipotesis $\mathrm{H}_{1}, \mathrm{H}_{2}, \mathrm{H}_{3}, \mathrm{H}_{4}$ yaitu pengaruh Indeks DJIA, N225, SSEC dan STI secara parsial terhadap IHSG. Menurut Ghozali (2011), uji t dilakukan dengan membandingkan signifikansi t hitung dengan tabel dengan ketentuan :

- $\mathrm{H}_{0}$ diterima dan $\mathrm{H}_{\mathrm{a}}$ ditolak jika $\mathrm{t}$ hitung $<\mathrm{t}$ tabel untuk $\alpha=0,05$

- $\mathrm{H}_{0}$ ditolak dan $\mathrm{H}_{\mathrm{a}}$ diterima jika $\mathrm{t}$ hitung $>\mathrm{t}$ tabel untuk $\alpha=0,05$

3) Koefisien Determinasi $\left(\mathrm{R}^{2}\right)$

Koefisien determinasi $\left(\mathrm{R}^{2}\right)$ pada intinya mengukur seberapa jauh kemampuan model menerangkan variasi variabel independen. Nilai $R^{2}$ yang kecil berarti kemampuan variabel-variabel dependen dalam menjelaskan variasi variabel dependen sangat terbatas, sebaliknya nilai $\mathrm{R}^{2}$ yang mendekati satu berarti variabel-variabel independen memberikan hampir semua informasi yang dibutuhkan untuk memprediksi variasi variabel dependen (Ghozali 2011). Nilai koefisien determinasi yang digunakan dalam penelitian ini adalah nilai adjusted $R^{2}$ karena variabel independen yang digunakan dalam penelitian ini lebih dari dua variabel. Selain itu nilai adjusted $\mathrm{R}^{2}$ dianggap lebih baik dari nilai $\mathrm{R}^{2}$, karena nilai adjusted $\mathrm{R}^{2}$ dapat naik atau turun apabila satu variabel independen ditambahkan ke dalam model regresi (Ghozali 2011).

\section{Hasil dan Pembahasan}

\section{Hasil}

\section{Analisis Diskriptif}

Analisis statistik deskriptif digunakan untuk mengetahui karakter sampel dalam penelitian ini seperti jumlah sampel yang diteliti nilai rata-rata, dan tingkat penyimpangan penyebaran data penelitian. Dalam penelitian ini menggunakan 4 independent variable yaitu Indeks Dow Jones, Nikkei 225, Shanghai Stock Exchange Composite Index dan Straits Times Index Singapore dengan menggunakan 1 dependent variable yaitu Indeks Harga Saham Gabungan (IHSG). Hasil analisis statistik deskriptif variabel penelitian dapat dilihat pada tabel dibawah ini (Tabel 4.1): 
Tabel 1. Descriptive Statistics

\begin{tabular}{|l|r|r|r|r|r|}
\hline & $\mathrm{N}$ & \multicolumn{1}{|c|}{ Minimum } & Maximum & \multicolumn{1}{c|}{ Mean } & Std. Deviation \\
\hline IHSG & 60 & 4223.91 & 6605.63 & 5628.6923 & 641.61694 \\
DJIA & 60 & 16284.70 & 28538.44 & 21801.0072 & 3793.54820 \\
N225 & 60 & 15575.92 & 24120.04 & 20123.6800 & 2172.47267 \\
SSEC & 60 & 2493.90 & 4611.74 & 3148.7470 & 396.92857 \\
STI & 60 & 2629.11 & 3613.93 & 3153.9880 & 238.58290 \\
Valid N (listwise) & 60 & & & & \\
\hline
\end{tabular}

\section{Analisis Regresi Berganda}

Berdasarkan pengolahan data menggunakan Eviews 10, diperoleh hasil regresi linier berganda seperti berikut (Tabel 4.2):

Tabel 2. Hasil Uji Regresi Liniear Berganda

\begin{tabular}{|c|c|c|c|c|}
\hline Variable & Coefficient & Std. Error & t-Statistic & Prob. \\
\hline C & 4.496236 & 23.85983 & 0.188444 & 0.8512 \\
\hline D(DJIA) & 0.122806 & 0.047950 & 2.561139 & 0.0133 \\
\hline D(N225) & 0.090390 & 0.038110 & -2.371832 & 0.0213 \\
\hline D(SSEC) & 0.012525 & 0.124711 & -0.100431 & 0.9204 \\
\hline D(STI) & 0.432615 & 0.280754 & 1.540902 & 0.1292 \\
\hline R-squared & 0.241824 & Mean dependent var & 17.12102 \\
\hline Adjusted R-squared & 0.185662 & S.D. dependent var & 191.9362 \\
\hline S.E. of regression & 173.2045 & Akaike info criterion & 13.22776 \\
\hline Sum squared resid & 1619989. & Schwarz criterion & 13.40382 \\
\hline Log likelihood & 385.2190 & Hannan-Quinn criter. & 13.29649 \\
\hline F-statistic & 4.305883 & Durbin-Watson stat & 2.103807 \\
\hline Prob(F-statistic) & 0.004271 & \multicolumn{4}{|l}{} \\
\hline
\end{tabular}

Berdasarkan Tabel 4.2 di atas perhitungan analisis regresi liniear berganda menggunakan program Eviews 10 mendapat hasil sebagai berikut:

$$
Y=0.188444+2.561139 X_{1}-2.371832 X_{2}-0.100431 X_{3}+1.540902 X_{4}
$$

Adapun interpretasi persamaan regresi dapat dijelaskan sebagai berikut:

1) Konstanta

Nilai konstanta sebesar 0.188444 artinya jika Indeks Dow Jones, Nikkei 225, Shang Hai Stock Exchange Composite Index dan Straits Times Index Singapore tidak mengalami perubahan atau konstan, maka Indeks Harga Saham Gabungan akan sebesar 0.188444 poin.

\section{2) Dow Jones $\left(X_{1}\right)$}

Nilai koefisien regresi dari Dow Jones $\left(b_{1}\right)$ sebesar 2.561139 dengan arah positif, artinya jika Indeks Dow Jones meningkat sebesar 1 poin maka harga saham gabungan akan meningkat sebesar 2.561139 poin dan sebaliknya jika Dow Jones menurun sebesar 1 poin maka Indeks Harga Saham Gabungan mengalami penurunan sebesar 2.561139 poin dengan asumsi variabel lain tetap. 


\section{3) Nikkei $225\left(\mathrm{X}_{2}\right)$}

Nilai koefisien regresi dari Nikkei $225\left(b_{2}\right)$ sebesar 2.371832 dengan arah negatif, artinya jika Indeks Nikkei 225 meningkat sebesar 1 poin maka harga saham gabungan akan menurun sebesar 2.371832 poin begitu juga sebaliknya jika Indeks Nikkei 225 menurun sebesar 1 poin maka harga saham gabungan akan meningkat sebesar 2.371832 poin dengan asumsi variabel lain tetap.

\section{4) Shanghai Stock Exchange Composite Index $\left(\mathrm{X}_{3}\right)$}

Nilai koefisien regresi dari Shanghai Stock Exchange Composite Index ( $\left.\mathrm{b}_{3}\right)$ sebesar 0.100431 dengan arah negatif, artinya jika Shanghai Stock Exchange Composite Index meningkat sebesar 1 poin maka harga saham gabungan akan menurun sebesar 0.85 poin begitu juga sebaliknya jika Shanghai Stock Exchange Composite Index menurun sebesar 1 poin maka harga saham gabungan akan meningkat sebesar 0.100431 poin dengan asumsi variabel lain tetap.

\section{5) Straits Times Index Singapore $\left(\mathrm{X}_{4}\right)$}

Nilai koefisien regresi Straits Times Index Singapore (b4) sebesar 1.540902 artinya jika Straits Times Index Singapore meningkat sebesar 1 poin maka harga saham gabungan akan meningkat 1.540902 poin begitu juga sebaliknya jika Straits Times Index Singapore menurun sebesar 1 poin maka harga saham gabungan akan menurun sebesar 1.193 poin dengan asumsi variabel lain tetap.

\section{Hasil Pengujian Hipotesis}

1) Uji Simultan (uji F)

Berdasarkan tabel 4.2 diperoleh nilai F-hitung sebesar 4.305883 dengan signifikansi = 0.004271. Berdasarkan ketentuan uji $\mathrm{F}$ dimana nilai F-hitung $\leq \alpha=0.05$ dapat disimpulkan bahwa Indeks Dow Jones, Nikkei 225, Shanghai Stock Exchange Composite Indeks dan Straits Times Index Singapore secara simultan berpengaruh terhadap Indeks Harga Saham Gabungan (IHSG), dengan demikian $\mathrm{H}_{1}$ diterima.

2) Uji Parsial (Uji t)

Hasil uji mengenai pengaruh Indeks Dow Jones, Indeks Nikkei 225, Shanghai Stock Exchange Composite Indeks dan Straits Times Index Singapore terhadap Indeks Harga Saham Gabungan (IHSG) secara parsial sesuai tabel 4.2 adalah sebagai berikut :

a. Hasil analisis menunjukkan bahwa variabel Indeks Dow Jones berpengaruh signifikan dengan arah positif terhadap Indeks Harga Saham Gabungan (IHSG). Dengan nilai signifikansi 0.0133 lebih kecil dari taraf signifikansi sebesar 0,05. Sedangkan koefisien regresi bernilai 0.122806 dan nilai $\mathrm{t}$ - hitung 2.561139, dengan demikian $\mathrm{H}_{2}$ diterima.

b. Hasil analisis menunjukkan bahwa variabel Indeks Nikkei 225 berpengaruh signifikan dengan arah negatif terhadap Indeks Harga Saham (IHSG). Dengan nilai signifikansi Indeks Nikkei 225 sebesar 0.0213 lebih kecil dari taraf signifikansi sebesar 0,05. Sedangkan koefisien regresi bernilai -0.090390 dan nilai $\mathrm{t}$ - hitung sebesar -2.371832, dengan demikian $\mathrm{H}_{3}$ diterima.

c. Hasil analisis menunjukkan bahwa variabel Shanghai Stock Exchange Composite Indeks tidak berpengaruh signifikan dengan nilai signifikansi sebesar 0.9204 lebih 
besar dari taraf signifikansi sebesar 0,05. Sedangkan koefisien regresi Shanghai Stock Exchange Composite Indeks bernilai -0.012525 dan nilai t - hitung sebesar 0.100431 , dengan demikian $\mathrm{H}_{4}$ ditolak.

d. Hasil analisis menunjukkan bahwa variabel Indeks Straits Times Singapore berpengaruh signifikan dengan arah positif terhadap Indeks Harga Saham Gabungan (IHSG). Dengan nilai signifikansi sebesar 0.1292 lebih kecil dari taraf signifikansi sebesar 0,05. Sedangkan koefisien regresi bernilai 0.432615 dan nilai t - hitung sebesar 1.540902, dengan demikian $\mathrm{H}_{5}$ ditolak.

3) Koefisien Determinasi (adjust. $\mathrm{R}^{2}$ )

Nilai Adjusted R Square digunakan untuk menilai besarnya kontribusi Indeks Dow Jones, Indeks Nikkei 225, Shanghai Stock Exchange Composite Indeks, dan Straits Times Index Singapore secara simultan terhadap Indeks Harga Saham Gabungan (IHSG) dapat dilihat pada tabel 4.6 sebesar 0.185662 yang artinya $18.5 \%$ Indeks Harga Saham Gabungan (IHSG) dipengaruhi oleh Indeks Dow Jones, Indeks Nikkei 225, Shanghai Stock Exchange Composite Indeks dan Straits Times Index Singapore. Sisanya sebesar $17.4 \%$ dipengaruhi oleh variabel lain diluar variabel yang digunakan dalam penelitian ini.

\section{Pembahasan}

\section{Pengaruh Indeks Dow Jones terhadap Indeks Harga Saham Gabungan (IHSG)}

Amerika yang menjadi salah satu negara dengan perekonomian terbesar tentunya akan mempengaruhi perekonomian negara - negara lain, karena itu perubahan ekonomi di Amerika Serikat sedikit banyak akan mempengaruhi perekonomian di Indonesia. Indeks Dow Jones merupakan rata-rata indeks harga saham terbesar di dunia yang berada di Pasar Modal Amerika. Amerika masih menjadi negara super power yang dapat mempengaruhi perekonomian Indonesia. Secara moneter, suku bunga yang diterapkan oleh Bank Indonesia keputusannya masih berdasarkan pergerakan The Fed. Ekspor-Impor diIndonesia masih menggunakan mata uang dollar Amerika, Oleh karena itu, pergerakan indeks Dow Jones dapat mempengaruhi hampir seluruh indeks harga saham dunia, termasuk IHSG di Indonesia. Indeks Dow Jones yang bergerak naik, menandakan kinerja perekonomian Amerika Serikat secara umum berada pada posisi yang baik. Dengan kondisi perekonomian yang baik, akan menggerakkan perekonomian Indonesia melalui kegiatan ekspor maupun aliran modal masuk, baik investasi langsung maupun melalui pasar modal. Penelitian ini mendukung penelitian Immanuel Satrio dan Gerianta Wirawan (2017).

\section{Pengaruh Indeks Nikkei 225 terhadap Indeks Harga Saham Gabungan (IHSG)}

Indeks Nikkei 225 yang merupakan salah satu indeks utama di negara Jepang, pergerakan indeks ini akan menjadi salah satu alat analisis oleh para investor, karena Nikkei 225 merupakan salah satu indeks yang sangat berpengaruh, hal ini di sebabkan oleh Negara Jepang merupakan Negara yang sangat mempengaruhi perputaran ekonomi dunia (Surbakti, 2011). Hasil dari penelitian ini menunjukkan bahwa Nikkei 225 berpengauh negatif signinifikan terhadap IHSG. Jepang yang sejak 2018 menghadapi gejolak ekonomi yang dapat membuat Jepang kemungkinan dapat resesi, mulai menurunya perekonomian Jepang yang mengalami kontraksi 2,5 persen pada kuartal ketiga tahun 2018, yang menandai kemerosotan terburuk dalam empat tahun terakhir, hal ini diperburuk dengan pernyataan 


\section{Didit Herlianto, Luthfi Hafizh}

"Sebanyak 28 dari 38 ekonom mengatakan, kemungkinan Jepang jatuh ke dalam resesi di tahun fiskal 2019" (internasional.kontan.co.id) yang mendorong presepsi investor memburuk. Ditambah pada Oktober 2019 pemerintahan Perdana Menteri Jepang meluncurkan kebijakan kenaikan pajak penjualan nasional dari 8 persen menjadi 10 persen, yang di khawatirkan akan dapat merugikan ekonomi di tengah perang dagang dan permintaan eksternal yang lesu. Karena hal tersebut indeks Nikkei 225 mengalami tren Bearish dari bulan Oktober 2018 sampai awal 2019 dan sempat menyentuh titik terendah pada saat itu pada angka 1900 an. Berbeda dengan IHSG yang sempat naik pada saat itu bahkan ke titik 6400an. Hal ini mungkin terjadi karena perlambatan pertumbuhan ekonomi Jepang yang sebesar $0,6 \%$ itu akan mengundang respon dari pemerintah dan otoritas moneter di masing-masing negara dalam bentuk kebijakan fiksal dan moneter yang lebih longgar. Kebijakan fiskal dan moneter yang longgar, khususnya di Ameria dan Eropa akan berdampak positif mendorong aliran modal asing ke negara-negara berkembang, termasuk Indonesia. Hal ini didukung juga dengan kebijakan pemerintah yang menjadi salah satu sentimen positif bagi pasar saham, dengan langkah pemerintah dalam menggiatkan kegitan investasi juga menjadi salah satu sentimen positif bagi investor. Dengan hal tersebut maka iinvestor akan lebih memilih menginvestasikan dana mereka ke Indonesia dengan tingkat risiko yang lebih rendah. Penelitian ini mendukung penelitian Immanuel Satrio dan Gerianta Wirawan (2017). Berbeda dengan penelitian I Wayan (2015) yang menyatakan bahwa N225 tidak berpengaruh terhadap IHSG.

\section{Pengaruh Shanghai Stock Exchange Composite Indeks terhadap Indeks Harga Saham Gabungan (IHSG)}

Cina yang menjadi salah satu negara tujuan expor Indonesia terbesar setelah Jepang, tentunya naik turunya indeks SSEC yang menjadi indeks utama negara Cina akan mempengaruhi pasar modal Indonesia. Hasil penelitian yang menyatakan bahwa indeks SSEC tidak berpengaruh terhadap IHSG karena adanya pengaruh - pengaruh lain yang menjadi pertimbangan oleh para investor, khususnya investor asing untuk menanamkan dananya di suatu pasar modal suatu negara. Pada 2015 Cina yang mengalami perlambatan ekonomi saat itu dicerminkan dengan anjloknya Indeks SSEC yang langsung bergerak bearish. Pada tahun 2019 Cina yang sedang ber konflik dengan AS dalam hal perang dagang yang menjadikan tidak stabilnya kondisi perekonomian Cina sendiri. Hal ini berdampak pasar modal Cina menjadi kurang diminati, karena besarnya risiko investasi yang akan diterima, terlebih untuk investor - investor asing. Oleh karena hal tersebut mereka lebih memilih untuk tetap mempertahankan dananya pada pasar modal negara lain ataupun instrumen investasi lainya. Investor yang semula menanamkan modalnya di Indonesia akan lebih memilih mempertahankan dananya, karena memiliki risiko yang lebih kecil dibandingkan dengan risiko ketika menanamkan modalnya di Cina.

\section{Pengaruh Indeks Straits Times terhadap Indeks Harga Saham Gabungan (IHSG)}

Dari data ekspor Indonesia menunjukkan bahwa ekspor Indonesia terbesar ke negara negara ASEAN, terbesar adalah ke Singapura dan dengan adanya perjanjian perdagangan bebas. Meskipun demikian perekonomian Indonesai yang mengalami pertumbuhan saat ini dan di dukung dengan investor dometik yang sudah mulai menguasai proporsi kepemilikan saham di Bursa Efek Indonesai (BEI), membuat Indeks STI yang merupakan cerminan perdagangan Singapore menjadi kurang di lirik investor Indonesia sebagai acuan untuk melihat arah pergerakan harga saham di Indoneisa. Ditambah saat penelitian ini berlangsung 
terjadi keadaan ekonomi yang lebih dipandang dapat mempengaruhi IHSG seperti trade war, dan kebijakan bank sentral Amerika. Berdasarkan hal tersebut dapat menjelaskan hasil dari penelitian ini yang menunjukkan bahwa STI tidak memiliki pengaruh terhadap IHSG.

\section{Simpulan}

Berdasarkan hasil analisis dari pengaruh Indeks Dow Jhones, Nikkei 225, Shang Hai Stock Exchange Composite Index dan Straits Times Index Singapore terhadap Indeks Harga Saham Gabungan (IHSG) di Bursa Efek Indonesia (BEI) Periode 2015-2019, maka dapat disimpulkan:

1) Indeks Dow Jhones, Nikkei 225, Shang Hai Stock Exchange Composite Index dan Straits Times Index Singapore secara bersama - sama berpengaruh signifikan terhadap Indeks Harga Saham Gabungan (IHSG) di Bursa Efek Indonesia (BEI) Periode 2015-2019.

2) Indeks Dow Jhones berpengaruh signifikan dengan arah positif terhadap Indeks Harga Saham Gabungan (IHSG) di Bursa Efek Indonesia (BEI) Periode 2015-2019.

3) Nikkei 225 berpengaruh signifikan dengan arah negatif terhadap Indeks Harga Saham Gabungan (IHSG) di Bursa Efek Indonesia (BEI) Periode 2015-2019.

4) Shang Hai Stock Exchange Composite Index tidak berpengaruh terhadap Indeks Harga Saham Gabungan (IHSG) di Bursa Efek Indonesia (BEI) Periode 2015-2019.

5) Straits Times Index Singapore tidak berpengaruh signifikan terhadap Indeks Harga Saham Gabungan (IHSG) di Bursa Efek Indonesia (BEI) Periode 2015-2019.

Terkait kesimpulan tersebut maka bagi peneliti selanjutnya dapat mengembangkan penelitian ini, dengan menambah variabel-variabel independen lain yang mempengaruhi Indeks Harga Saham Gabungan (IHSG) di Bursa Efek Indonesia (BEI). Dan dapat menggunakan penelitian ini sebagai referensi penelitian, agar diperoleh hasil yang lebih baik.

\section{Daftar Referensi}

Bery Dicky, Worokinasih Saparila. 2018. Pengaruh INdeks Saham Global Terhadap Indeks Harga Saham Gabungan (IHSG). Jurnal administrasi Bisnis (JAB), Vol 64 No 1.

Banner, R.J dan K.F Kroner. 1995. Arbitrage, Cointegration and Testing the Unbiasedness hypotesis in Financial Markets. The Journal of Financial and Quatitaitive Analysis. p 23-42.

Blanchard, Olivier. 2006. European unemployment: the evolution of facts and ideas. Journals Social Sciences Economic Policy Volume 21 Issue 45 P 6-59. Oxford Universiy Press.

Charles, P. Jones. 2006. Invesment: Analysist and Management. Ninth edition, New York: John Wliley \& Sons Inc.

Darmadji, M. Dan M. Fakhrudin. 2001. Pasar Modal Di Indonesia. Jakarta: Salemba Empat.

Dornbusch, Rudiger, Yung Chul Park dan Stijn Claessens. 2000. Contagion: Why Crises Spread and How This Can Be Stopped. IMF Economic Review paper. Researhcgate.

Danardono, Gurnito Ari. 2016. Analisis Determinan Perubahan Indeks Harga Saham Gabungan (IHSG) Di Bursa Efek Indonesia (BEI). Jurnal Manajemen Bisnis Indonesia (JMBI). Universitas Negeri Yogyakarta, Vol 6 No 5.

Didin Fatihudin. 2017. Panduan Praktis Merencanakan Keuangan Untuk Investasi di Pasar Modal, Surabaya: Pasar Uang dan Valas. P3i UM Surabaya. 
Eun. C., S. Shim. 1989. Internasional Transmission of Stock Market Movement. Journal of Financial and Quantitative Analysis Volume 24 No 2 June 1989. University of Washington School.

Hartono, Jogiyanto, 2017. Teori Portofolio dan Analisis Investasi, Edisi Kesebelas, Yogyakarta: BPFE.

Jul Fahmi Salim, Abd. Jamal, Chenny Seftarita. 2017. Pengaruh Faktor Dalamdan Luar Negeri Terhadap Indeks Harga Saham GABUNGAN (IHSG) di Indonesia. Jurnal Ekonomi dan Kebijakan Publik Indonesia, Volume 4 Nomor 1.

Gusti Ayu Diah Akua Miyanti, Luh Putu Wiagusti. 2018. Pengaruh Suku Bunga The Fed, Harga Minyak, Dan Inflasi Terhadap IHSG. Jurnal Ekonomi dan Bisnis Universitas Udayana.

Ghozali, Imam. 2011. Aplikasi Analisis Multivariate Dengan Program SPSS. Semarang: Badan Penerbit Universitas Diponegoro.

Ghozali, Imam. 2016. Aplikasi Analisis Multivariete Dengan Program IBM SPSS 23 (Edisi 8). Cetakan ke VIII. Semarang: Badan Penerbit Universitas Diponegoro.

Gujarati, N. D. 2008. Basic Econometrics, Third Edition, MacGraw-Hill, New York. Hjalmarsson, Erik dan Pas Osterholm. Testing fot Cointegration using the 2007. Johansen Methodology when Variables are near-integrated. IMF Working Paper.

Nachrowi, N. D. \& H. Usman. 2006. Pendekatan Populer dan Praktis Ekonometrika Untuk Analisis Ekonomi dan Keuangan. Lembaga Penerbit FEUI, Jakarta.

Istijanto, 2009.Aplikasi Praktis Riset Pemasaran, Jakarta: Gramedia Pustaka Utama.

Immanuel Satrio, Wicaksono. Yasa Gerianta Wirawan. 2017. Pengaruh Fed Rate, Indeks Dow Jones, Nikkei 225, Hangseng terhadap Indeks Harga Saham Gabungan. Jurnal Akuntansi Universitas Unadaya, Vol 18 Nol.

Mauliano, Deddy Azhar. 2009. Pengaruh Indeks Bursa Global Terhadap Harga Saham Gabungan (IHSG) pada Bursa Efek Indonesia, Jurnal Ekonomi. Universitas Gunadarma.

Santoso Budi, Murhadi Werner R, Ernawati Endang. 2013. Analisis Pengaruh Ekonomi Makro, Indeks Dow Jones, dan Nikkei 225 Terhadap Indeks Harga Saham Gabungan Di BEI Periode 2007 - 2011. Jurnal Ilmiah Mahasiswa Universitas Surabaya, Vol 2 No 1.

Samsul, Mohammad. 2006. Pasar Modal dan Manajemen Portofolio. Surabaya: Erlangga.

Sunariyah. 2011. Pengantar Pengetahuan Pasar Modal. Edisi Ke Enam. Yogyakarta: UPP STIM YKPN.

Surbakti, Edy Priyatna Anugrah. 2011. Pengaruh Non Farm Payroll, Suku Bunga Bank Sentral Amerika Serikat (The Fed). Dan Indeks Nikkei 225 terhadap Indeks dari Saham - saham Perusahaan Berbasis Syariah di Jakarta Islmic Index. Jurnal Akuntansi Vol 3 No 1 Mei 2011. Universitas Maranatha.

Tamara, Shevanda Febrilia. 2013. Pengaruh Dow Jones Industrial Average, Deutscher Aktienindex, Shanghai Stock Exchange Composite Index, dan Straits Times Index Terhadap Indeks Harga Saham Gabungan di Bursa Efek Indonesia (Periode 2010-2012). Jurnal Ilmiah Mahasiswa FEB Universitas Brawijaya.

Tandelilin, Eduardus. 2010. Portofolio dan Investasi: Teori dan Implikasi. Yogyakarta: Kanisius.

Tarigan, Razaq Dastanta. Suhadak. Topowijono. 2015. Pengaruh Indeks Harga Saham Global Terhadap Indeks Harga Saham Gabungan (IHSG) Studi Pada Bursa Efek Indonesia 
INOBIS: Jurnal Inovasi Bisnis dan Manajemen Indonesia

Volume 03, Nomor 02, Maret 2020

Didit Herlianto, Luthfi Hafizh

(BEI) Periode 2011-2014. Fakultas Ilmu Administrasi Jurnal Administrasi Bisnis (JAB) Vol. 24 No. 1 Juli 2015.

Tcandrasa Benny Budiawan, Sutjiati Rosemary. 2016. Effect Of Gold Price, Crude Oil Price, and Interest rate to Jakarta Composite Index. International Journla of Education and Research, Vol 4 No 7.

Widodo. 2018. Analsis Pengaruh Indeks Harga Saham Gabungan Regional Asia Terhadap Indeks Harga Saham Gabungan Indonesia. Jurnal Ekonomi dan Bisnis Fakultas Ekonomi dan Bisnis Islam Universitas Islam Negeri Sunan Kalijaga Yogyakarta Vol. 1 No. 2. Halaman $148-164$. 